\title{
THE EFFECT OF DIFFERENT NANOCATALYSTS FOR PHOTOCATALYTIC DEGRADATION OF METHYLENE BLUE
}

\author{
Ayşegül Pala ${ }^{1^{*}}$, Güneş Kurşun ${ }^{2}$ \\ ${ }^{1}$ Department of Environmental Engineering, Dokuz Eylul University, Buca, Izmir, Turkey \\ ${ }^{2}$ Natural and Applied Sciences, Dokuz Eylul University, Buca, Izmir, Turkey \\ *E-mail of corresponding author: aysegul.pala@deu.edu.tr
}

\begin{abstract}
The aim of this study was to investigate photodegradation of Methylene Blue (MB) in water by using $\mathrm{ZnO}$ and $\mathrm{TiO}_{2}$ nanoparticles. Adsorption and photocatalytic oxidation studies were carried out by using produced $\mathrm{TiO}_{2}$, commercial $\mathrm{TiO}_{2}$ and commercial $\mathrm{ZnO}$ nanoparticles. In order to evaluate performance tests, $5 \mathrm{mg} / \mathrm{l}$ of $\mathrm{MB}$ solution was used. The samples were mixed in the dark for 2 hours for establishing adsorption-desorption equilibrium. The photocatalytic tests of the samples were performed by assessing the decomposition rate of MB solutions under UV light. The results of the photocatalytic showed that the highest color removal efficiencies was obtained by $\mathrm{TiO}_{2}$ catalyst where Methylene blue solution was completely degraded.
\end{abstract}

Keywords: $\mathrm{TiO}_{2}, \mathrm{ZnO}$, Photocatalytic Degradation, Methylene Blue

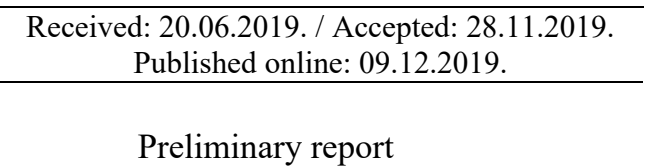

\section{INTRODUCTION}

Water plays an important role in human, animal life, and ecosystem, but any unwanted addition of chemical substances leads to contamination or pollution and makes it unfit for consumption. Lately, environmental pollution is becoming the world debating and challenging problem. Among all those problems, water pollution is of prime concern. Water pollution has become an important problem at the global scale. Anthropogenic and industrial activities are responsible for this pollution. Effluents are discharged directly or indirectly by the industries into the nearby water resources without proper treatment (Ameta et al. 2013).

The degradation of dyes in industrial effluent has attracted great attention in the recent years because of increasing environmental awareness and the application of environmental rules. However, some treatments for colour removal from these effluents do not guarantee the absence of other secondary toxic substances, often arising from the treatment process itself (Immich et al. 2009).

In recent years, photocatalytic specialized materials and devices are increased not only in academic case but also in industrial applications. This dramatic rise is accompanying the population growth and wastes which are increased by them. New technological improvements are invented continuously. Owing to the environmental pollution, these new approaches should be eco-friendly. In 1969, according to a Japan researcher called Fujishima, photocatalysts were used for the treatment process. Honda-Fujishima developed a prototype: fine powders which are doped with metal and/or metal oxide particles were used as a photocatalyst in chemical reactions. These fine powders were semiconductor. Photocatalytic reactions using $\mathrm{TiO}_{2}$ were discovered. Among these years many researches were done to improve the photocatalytic systems (Kodama \& Suzuki 2007).

In photocatalysis, light of energy greater than the band gap of the semiconductor, excites an electron from the valence band to the conduction band (Figure 1). In the case of anatase $\mathrm{TiO}_{2}$, the band gap is $3.2 \mathrm{eV}$, therefore UV light $(\lambda \leq 387 \mathrm{~nm})$ is required. The absorption of a photon excites an electron to the conduction band (e-CB) generating a positive hole in the valence band (Pelaez et al. 2012).

One of the advanced oxidation processes convenient for drinking water is heterogeneous photocatalysis with semiconductor titanium dioxide $\left(\mathrm{TiO}_{2}\right)$. $\mathrm{TiO}_{2} / \mathrm{UV}$ photocatalytic oxidation process is generally with solar energy $(\mathrm{h} v)$ and $\mathrm{TiO}_{2}$ surface. The main aim is to generate hydroxyl radical $(\mathrm{OH} \bullet)$ which is a strong oxidizer and participates in different reactions with adsorbed substances on this surface (Çakıroğlu 2011).

Zinc oxide $(\mathrm{ZnO})$ nanomaterials provide great usage because of their specifications in electronics, optics and photonics. Due to this reason, the properties of $\mathrm{ZnO}$ nanostructures, which have application potential in different areas, and $\mathrm{ZnO}$ is an environmentally friendly (Guo 2017).

Methylene blue is an aromatic chemical compound. The papers, hair dye, fabric dying and wool dying industry widely use MB as a colourant. The most MB is used in textile industry. It is commonly used in dyestuff applications and as a redox indicator. The mostly used wavelengths of MB are 291 and $664 \mathrm{~nm}$ (Yao and Wang 2010). 
The aim of this study was to perform the photocatalytic degradation tests of $\mathrm{MB}$ in water by using $\mathrm{ZnO}$ and $\mathrm{TiO}_{2}$ nanoparticles. Adsorption and photocatalytic oxidation studies were carried out by using produced $\mathrm{TiO}_{2}$, commercial $\mathrm{TiO}_{2}$ and commercial $\mathrm{ZnO}$ nanoparticles.

\section{MATERIALS AND METHODS}

\subsection{Preparation and supplying of materials}

$\mathrm{TiO}_{2}, \mathrm{ZnO}$ and Methylene Blue (MB) were used in the experiment. $\mathrm{TiO}_{2}$ was produced in Electronical Materials Production and Application Center of Dokuz Eylul University (99.55\% purity, $18 \mathrm{~nm}$, anastas) (Yildırım et al. 2016); commercial $\mathrm{TiO}_{2}$ (99 \%purity) and $\mathrm{ZnO}(99.5 \%$ purity) 30-50 nm were bought from Nanograph Company. MB (Sigma-Aldrich, $97 \%$ ) solution was prepared by adding $5 \mathrm{mg}$ of MB to 1 liter of deionized water. For providing the homogeny mix, 30 minutes of stirring was done with using magnetic mixer.

For every experiment, the beakers were filled up to $50 \mathrm{ml}$ and the nanoparticles of $\mathrm{TiO}_{2}$, commercial $\mathrm{TiO}_{2}$ and $\mathrm{ZnO}$ placed on the testing apparatus as shown in Figure 1. $\mathrm{ZnO}, \mathrm{TiO}_{2}$ and commercial $\mathrm{TiO}_{2}$ were added in $\mathrm{MB}$ solutions as $0,05 \mathrm{~g} / 50 \mathrm{ml}, 0,1 \mathrm{~g} / 50 \mathrm{ml}$ and $0,2 \mathrm{~g} / 50 \mathrm{ml}$, respectively. In the beginning, adsorption study was performed in the dark for 2 hours to establish adsorption-desorption equilibrium. After this step, photocatalytic studies were performed under UV lamp. Control sample (CS) were a reference samples without any photocatalyst. CS1 and CS2 were used to observe the effect of adsorption and photocatalytic studies. Schematic experiment apparatus was used in adsorption and photocatalytic studies as shown in Figure 1.

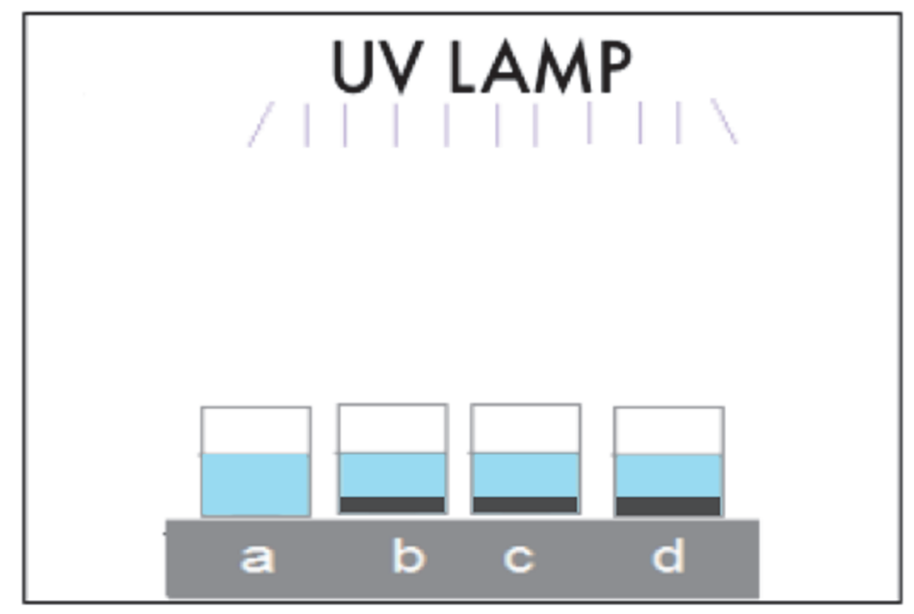

Figure 1. Schematic experiment apparatus, (a) Control Sample, (b) MB soluton with $\mathrm{ZnO}$ nanoparticle, (c) MB solution with commercial $\mathrm{TiO}_{2}$, (d) $\mathrm{MB}$ solution with produced $\mathrm{TiO}_{2}$

Initial absorbance was determined as Ao, and absorbance value of different times was determined as $\mathrm{Ai}$, following the Equation 1:

$$
\% \text { Degradation rate }=\left(\mathrm{A}_{0}-\mathrm{A}_{\mathrm{i}}\right) / \mathrm{A}_{0} \times 100
$$

The degradation rate was calculated by using the Eq. 1. All samples were shaked in WISD Orbital Shaker (Korea) device for 2 hours in dark to establish the equilibrium for adsorption. $10 \mathrm{ml}$ from each sample was taken for measurement of absorbance. Absorbance measurements were performed with Shimadzu UV-mini 1240 UVVis spectrophotometer (Japan). Photocatalytic degradation performance tests were carried out under UV lamp for 5 hours. After UV lamp exposure, all samples were taken for measurement of absorbance values. SEM analysis was performed to investigate surface morphology and characteristics of $\mathrm{TiO}_{2}$ by using JEOL JSM-6060 SEM (United States).

\section{RESULTS AND DISCUSSION}

\subsection{Characterization}

The $\mathrm{TiO}_{2}$ samples were characterized by using Scanning Electrone Microscope (SEM) and XRD. The morphology of the $\mathrm{TiO}_{2}$ nanoparticle was found to be affected by solution concentration and illustrated in Figure 2. The size distribution of $\mathrm{TiO}_{2}$ nanoparticles was homogeneous. Spectrophotometric measurement results are shown in Figures 4-5. The morphology of the films is an important parameter that affects photocatalytical properties (Bakuy 2009). It is noted that $\mathrm{TiO}_{2}$ nanoparticles distribution is non-uniform. 


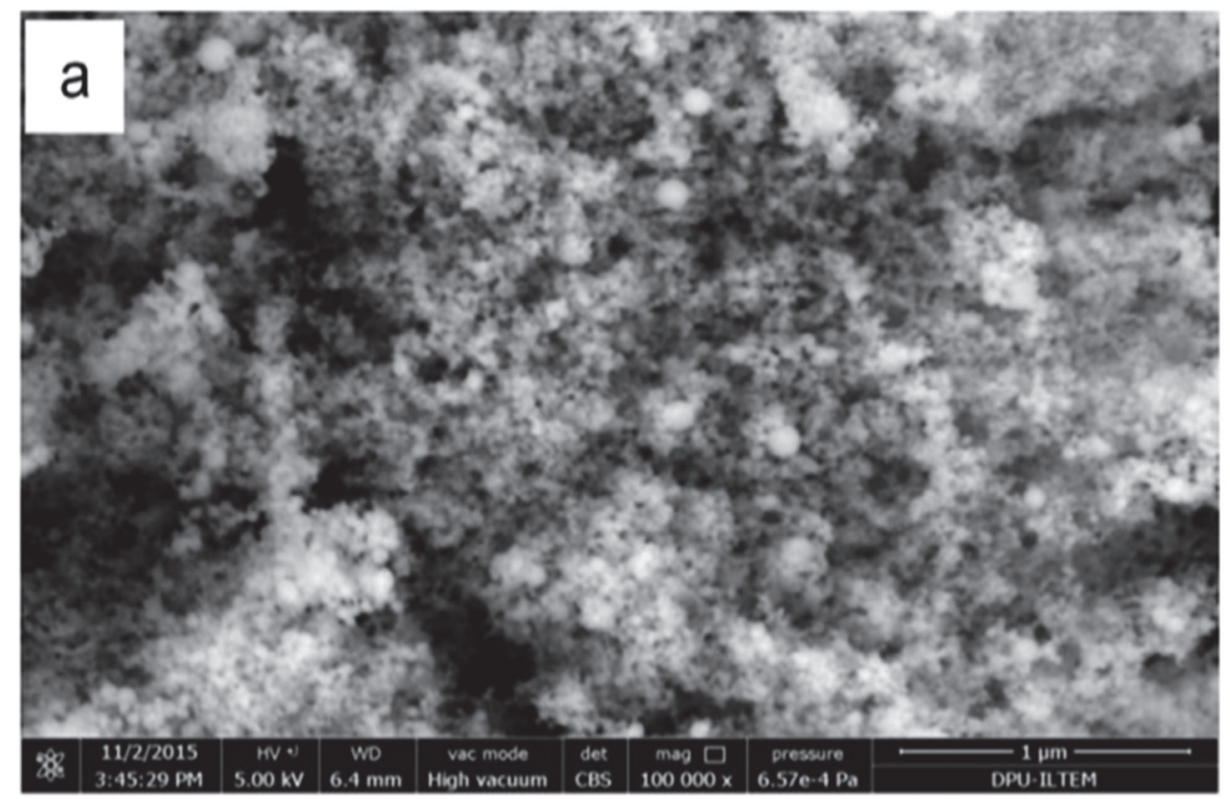

Figure 2. SEM micrograph of $\mathrm{TiO}_{2}$

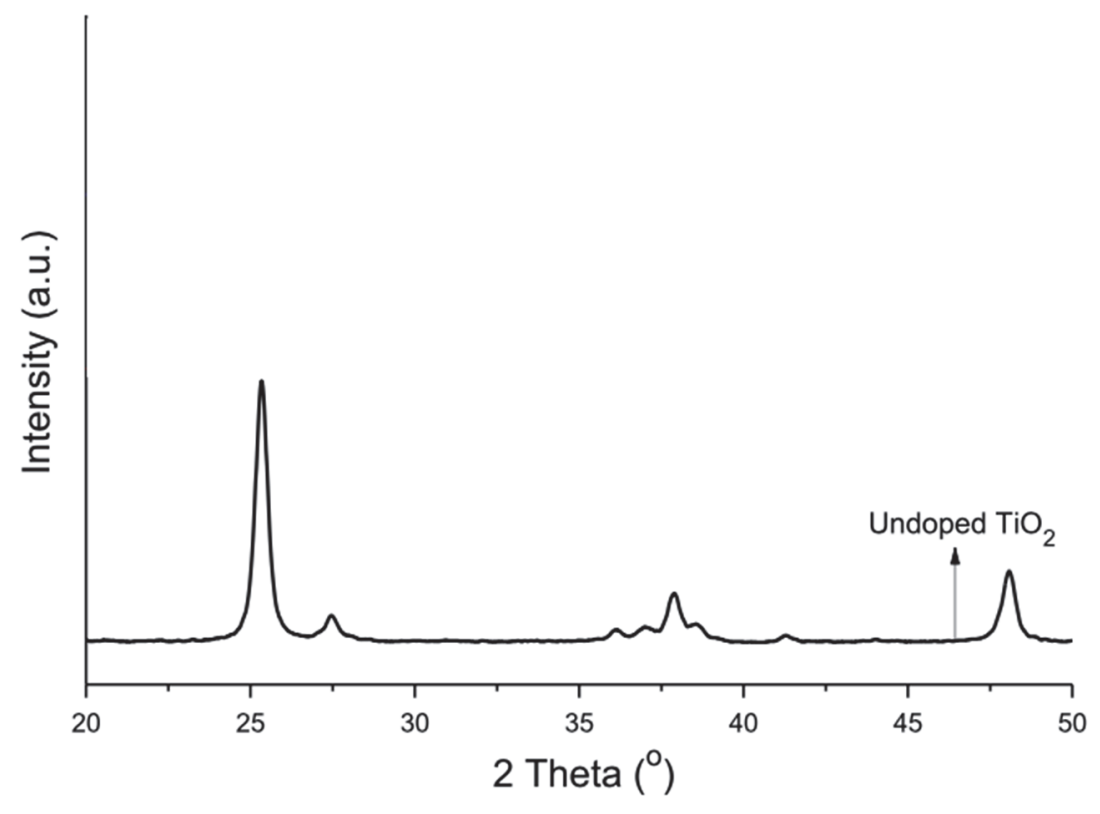

Figure 3. XRD graph of $\mathrm{TiO}_{2}$

Phase identification of the $\mathrm{TiO}_{2}$ was performed using X-Ray Diffraction (XRD) and illustrated in Figure 3. It was noted that strong and sharp peaks of the patterns confirmed. The obtained diffraction peaks were matched very well with the JCPDS Card no.: 21-1272 and 86-0148 demonstrating the phases of $\mathrm{TiO}_{2}$ (Y1ldırım et al. 2016).

\subsection{Degradation}

The degradation of the color during adsorption study was shown in Figure 4. It was noted that there was no significant color change after the adsorption study for all three nanoparticle photocatalysts; commercial $\mathrm{TiO}_{2}-1$, prepared $\mathrm{TiO}_{2}-2$ and $\mathrm{ZnO}$ (at three different concentrations of photocatalysts $0.05,0.1$ and 0.2 ). As expected, during the photocatalysis the colr removals appeared (Figure 5) for all three nanoparticle photocatalysts; commercial $\mathrm{TiO}_{2}-1$, prepared $\mathrm{TiO}_{2}-2$ and $\mathrm{ZnO}$ (at three different concentrations of photocatalysts $0.05,0.1$ and 0.2). The higherst degradation rates were obtained by the use of both types of $\mathrm{TiO}_{2}$ nanoparticles - commercial $\mathrm{TiO}_{2}-1$, prepared $\mathrm{TiO}_{2}-2$. 


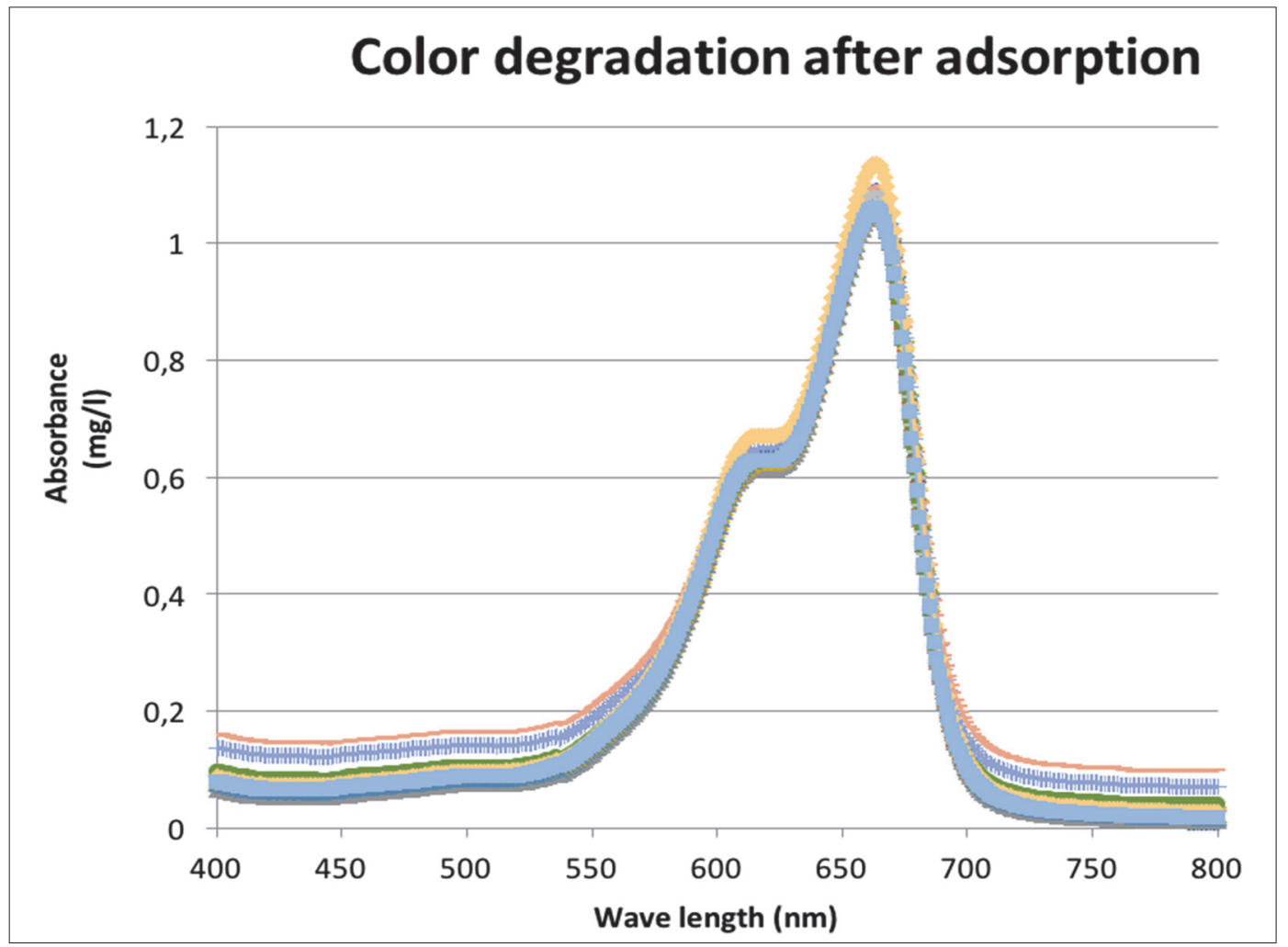

Figure 4. Color degradation after adsorption on commercial $\mathrm{TiO}_{2}-1$, prepared $\mathrm{TiO}_{2}-2$ and $\mathrm{ZnO}$ nanoparticles; at three different concentrations of photocatalysts

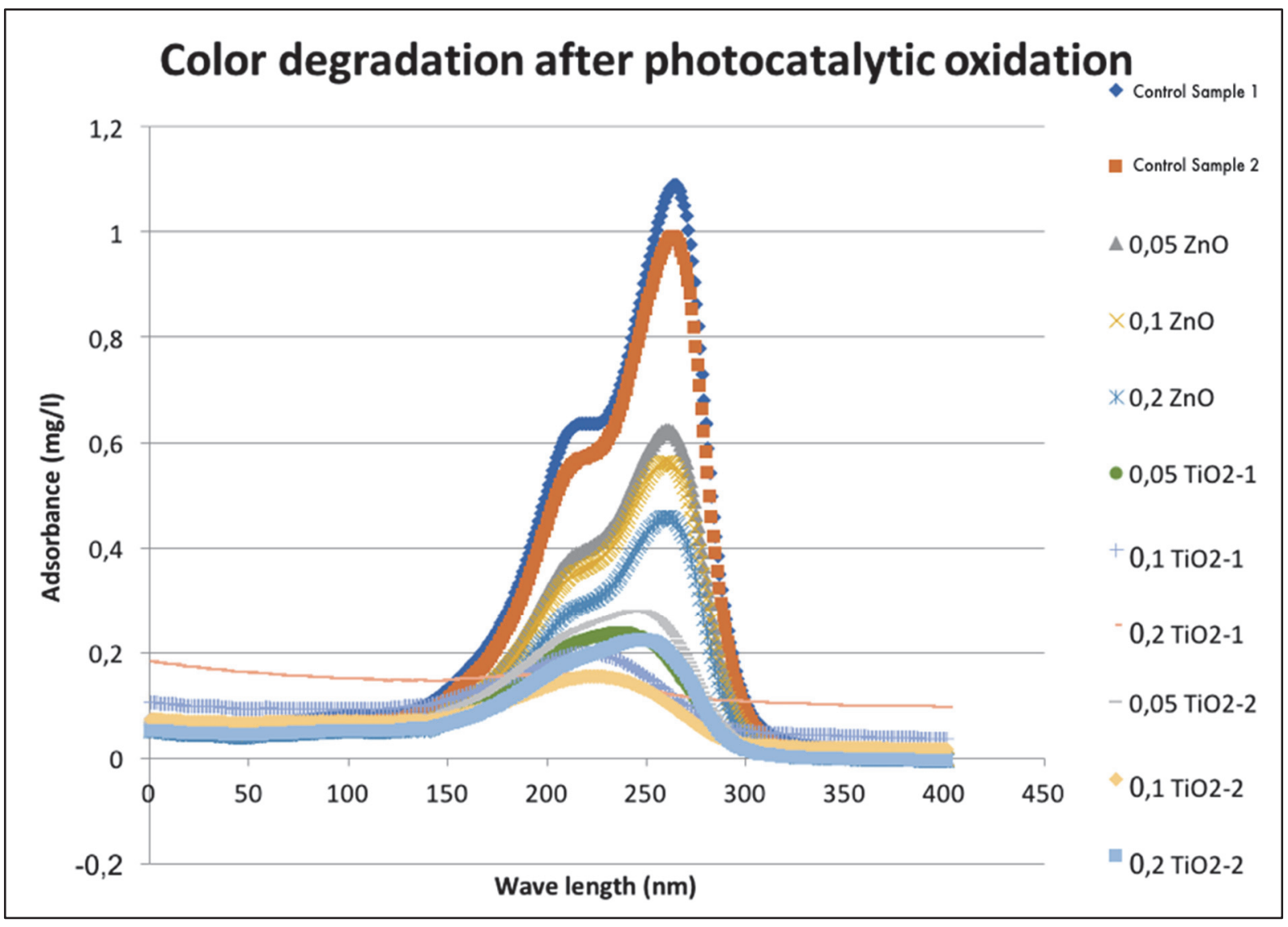

Figure 5. Photocatalytic color degradation after adsorption on commercial $\mathrm{TiO}_{2}-1$, prepared $\mathrm{TiO}_{2}-2$ and $\mathrm{ZnO}$ nanoparticles; at three different concentrations of photocatalysts 
The photocatalytic experiment results are illustrated in Table 1 and shown in Figure 5. A slight change can be seen at reference (control) sample during the test. It was found that the samples with $\mathrm{TiO}_{2}$ photocatalyst was removed totally $\mathrm{MB}$ in water, successfully. The $\mathrm{MB}$ degradation was very weak with $\mathrm{ZnO}$ catalyst in comparison with $\mathrm{TiO}_{2}$ catalyst. Although it was found that $72 \%$ degradation efficiency, it is possible to make nanoparticle more effective using on thin film coating with different dopant elements (Yang et al. 2009).

Table 1. Percentage of degradation after photocatalytic oxidation

\begin{tabular}{|c|c|c|}
\hline NAME OF SAMPLE & $\begin{array}{c}\text { RESIDUE MB CONCENTRATION } \\
(\mathbf{m g} / \mathbf{l})\end{array}$ & EFFICIENCY (\%) \\
\hline Control Sample & 4,55 & 11 \\
\hline $0.05 \mathrm{ZnO}$ & 2,37 & 54 \\
\hline $0.1 \mathrm{ZnO}$ & 2,02 & 72 \\
\hline $0.2 \mathrm{ZnO}$ & 1,43 & 100 \\
\hline $0.05 \mathrm{TiO}_{2}(\mathrm{p})^{*}$ & 0 & 100 \\
\hline $0.1 \mathrm{TiO}_{2}-1(\mathrm{p})^{*}$ & 0 & 100 \\
\hline $0.2 \mathrm{TiO}_{2}-1(\mathrm{p})^{*}$ & 0 & 100 \\
\hline $0.05 \mathrm{TiO}_{2}(\mathrm{c})^{* *}$ & 0 & 100 \\
\hline $0.1 \mathrm{TiO}_{2}(\mathrm{c})^{* *}$ & 0 & 100 \\
\hline $0.2 \mathrm{TiO}_{2}(\mathrm{c})^{* *}$ & 0 & \\
\hline
\end{tabular}

*Produced $\mathrm{TiO}_{2}$ in $\mathrm{EMUM}\left(\right.$ Ylldirlm et al., 2016) **Commercial $\mathrm{TiO}_{2}$

\section{CONCLUSION}

Adsorption and photocatalytic oxidation studies with $\mathrm{ZnO}$, commercial $\mathrm{TiO}_{2}$ and produced $\mathrm{TiO}_{2}$ catalysts were performed successfully. As a result of the photocatalytic performance studies, the highest efficiencies were reached with the $\mathrm{TiO}_{2}$ (both commercial and produced $\mathrm{TiO}_{2}$ obtained $100 \%$ efficiency) compared to $\mathrm{ZnO}$ nanoparticles (up to $70 \%$ efficiency).

\section{REFERENCES}

Ameta R, Benjamin S, Ameta A, Ameta SC (2013) Photocatalytic degradation of organic pollutants: A review. Mater Sci Forum 734: 247- 272

Bakuy Ş (2009) Kirli su temizleme uygulamaları için cam altlıklar üzerine $\mathrm{Ru}^{-\mathrm{TiO}_{2}}$ ince film üretimi ve fotokatalitik özelliklerinin incelenmesi. Dokuz Eylul University, Dissertation Thesis, Izmir.

Çakıroğlu E (2011) Titanyum Dioksit Esaslı $\left(\mathrm{TiO}_{2}\right)$ Fotokatalizör Kullanılarak Toksik Madde İçerikli Atık Suların Detoksifikasyonu, İzmir.

Dhananjeyan MR, Kandavelu V, Renganathan R (2000) A study on the photocatalytic reactions of TiO2 with certain pyrimidine bases: effects of dopants $\left(\mathrm{Fe}^{3+}\right)$ and calcination. J Mol Catal A-Chem 151: 217

Fabiyi ME, Skelton RL (2000) Photocatalytic mineralisation of methylene blue using buoyant $\mathrm{TiO}_{2}$-coated polystyrene beads. J Photoch Photobio A 132: 121

Guo K, (2017) Property of Zinc Oxide (ZnO) Nanostructures Potential for Biomedical System and Its Common Growth Mechanism. J appl biotechnol bioeng 2 (5): 197-202

Immich APS, Souza AAU, Souza SMAGU (2009) Removal of Remazol Blue RR dye from aqueous solutions with Neem leaves and evaluation of their acute toxicity with Daphnia magna. J Hazard Mater 164: 1580-1585

Kodama F, Suzuki J (2007) How Japanese Companies have used scientific advances to restructure their business: The receiver-active national system of innovation. World Dev 35 (6): 976-990

Pelaez M, Nolan NT, Pillai SC, Seery MK, Falaras P, Kontos AG, et al (2012) A review on the visible light active titanium dioxide photocatalysts for environmental applications. Appl Catal B-Environ 125: 331-349

Yang Y, Chen Q, Yin Z, Li J (2009) Study on the photocatalytic activity of $\mathrm{K}_{2} \mathrm{La}_{2} \mathrm{Ti}_{3} \mathrm{O}_{10}$ doped with vanadium (V). J Alloy Compd 488: 364-369

Yao J, Wang C (2010) Decolorization of methylene blue with $\mathrm{TiO}_{2}$ sol via UV irradiation photocatalytic degradation. Int J Photoenergy 1: 6-12

Yıldırım S, Yurddaskal M, Dikici T, Aritman I, Ertekin K, Celik E (2016) Structural and luminescence properties of undoped, $\mathrm{Nd}^{3+}$ and $\mathrm{Er}^{3+}$ doped $\mathrm{TiO}_{2}$ nanoparticles synthesized by flame spray pyrolysis method. Ceram Int 42 (9): 1057910586 